International Research Journal of Management, IT \& Social Sciences
Available online at https://sloap.org/journals/index.php/irjmis/
Vol. 6 No. 4, July 2019, pages: 44 53
$\begin{aligned} & \text { ISSN: 2395-7492 } \\ & \text { https://doi.org/10.21744/irjmis.v6n4.641 }\end{aligned}$

\title{
Ability of Organizational Commitment and Emotional Intelligence Moderating Effect of Role Stress on Turnover Intention
}

I Made Arya Dwiputra ${ }^{\text {a }}$ Ida Bagus Putra Astika ${ }^{\text {b }}$

Article history:

Received: 27 March 2019

Accepted: 31 May 2019

Published: 8 June 2019

\section{Keywords:}

commitment; emotional intelligence;

organizational;

role stress;

turnover intentions,

\begin{abstract}
This research was conducted to obtain empirical evidence of the influence of role stress on turnover intentions of tax consultants in Tax Consultant Offices in Bali Province with organizational commitment and emotional intelligence as moderating variables. This research was conducted at 35 Tax Consultant Offices in Bali Province. The research sample was determined by purposive sampling method and based on the specified criteria obtained a total sample of 185 respondents. Data collection is done using the questionnaire method. The hypothesis is tested using simple regression analysis techniques and the Moderating Regression Analysis (MRA). The results showed that role stress had a significant positive effect on turnover intentions. Organizational commitment and emotional intelligence show weakening the positive influence of role stress on turnover intentions.
\end{abstract}

2395-7492@ Copyright 2019. The Author. This is an open-access article under the CC BY-SA license (https://creativecommons.org/licenses/by-sa/4.0/) All rights reserved.

\section{Author correspondence:}

I Made Arya Dwiputra,

Faculty of Economics and Business, Udayana University, Denpasar, Indonesia

Jalan P.B. Sudirman, Dangin Puri Kelod, Denpasar, Bali 80234

Email address: aryadwiputra453@yahoo.com

\section{Introduction}

The cause of stress experienced by the accounting profession is being trapped in a situation that cannot be separated from role stress in work. Kahn et al., (1964), stated that pressure in work arises because of three conditions that are often faced by the accounting profession, namely role ambiguity, role conflict, and role overload.

Wiryathi et al., (2014), states that role conflict occurs when there is a mismatch of expectations and demands related to the role a person is living in, where fulfilling expectations for one role makes fulfilling other roles more difficult. Role conflict is a conflict or confusion that occurs because of the appearance of two or more commands that come in a row but are inconsistent. This will make someone work more extra than usual to meet those needs.

Role ambiguity according to Yousef (2002), is a situation where individuals do not have a clear direction about the expectations of their role in the organization. Role ambiguity is a condition of stress caused by confusion because role

\footnotetext{
a Faculty of Economics and Business, Udayana University, Denpasar, Indonesia ${ }^{\mathrm{b}}$ Faculty of Economics and Business, Udayana University, Denpasar, Indonesia
} 
expectations are not clearly understood and there is no adequate information needed by someone to fulfill their role satisfactorily (Wiryathi et al., 2014).

Mondy et al., (1990), states that role overload is a more complex type of role conflict, occurs when expectations sent to role holders can be combined but their performance exceeds the amount of time available to people who carry out the expected activities. Accountants are busy working for more than ten hours a day for a month (Jones et al., 2010). Sweeney \& Summer (2002), found that at the end of the busy season the accounting profession experienced a significant increase in emotional exhaustion. Research by Fogarty et al., (2000), stated a positive relationship between role conflict, role ambiguity, role overload on the desire to move.

Gaertner \& Ruhe (1981), state that the profession in accounting is a profession that has a high level of stress. Gaertner \& Ruhe (1981), also mentioned that many accountants reported having smoking, drinking, gastritis, back pain, and headaches due to the stress they experienced. In addition, in carrying out their duties, accountants engage in boundary-spanning activities, namely accountants must interact with many people from inside and outside the organization with different needs and expectations, to obtain useful information in decision making (Farrastama et al., 2019). Individuals who are in a boundary-spanning situation have the potential to experience role pressures.

According to the Minister of Finance Decree Number 111 / KMK.03 / 2014, tax consultants are people who provide tax consulting services to taxpayers in order to exercise their rights and fulfill their tax obligations in accordance with tax laws and regulations. Based on this, the tax consultant helps taxpayers carry out tax obligations in the form of calculation, payment, and reporting of tax obligations. This is an implementation of the self-assessment system. In addition, tax consultants can also represent taxpayers in terms of tax audits or tax courts.

Self-assessment system frees taxpayers to carry out their own calculation, payment and tax reporting processes (Official, 2011). These conditions make many taxpayers who carry out tax obligations not in accordance with tax regulations and many taxpayers who do not understand the tax rules. So that there are often misinterpretations of tax rules. This is also due to too many tax rules in Indonesia and the frequent changes in tax rules.

Under these conditions, many taxpayers require tax consultants to direct and assist taxpayers to handle their tax obligations. These conditions will make tax consultants require extra time in fostering taxpayers who are clients. So that it will cause overwork. Increasing working hours is one of the stressors (Breakwell, 1990). Tax consultants, directly and indirectly, provide education regarding tax rules. Many things faced by tax consultants in educating taxpayers, including the wishes of each taxpayer, tax issues faced by taxpayers and the characteristics of different taxpayers, so that it becomes one of the stressors.

In addition to interacting with many parties, tax consultants also accommodate different desires from various parties. One of them accommodates the taxpayer's desire to reduce the tax payable and even approach the tax employee to be more profitable to the taxpayer. As in the case of Hendro Tirtawijaya who approached and negotiated with tax officials to reduce the amount of tax payable (news.okezone.com). If already involved in such cases, tax consultants are susceptible to stress, as is the case with Imam Cahyo Maliki, a tax consultant who experienced stress because he was allegedly involved in the Gayus case and was undergoing therapy (www.rmol.co).

There are inconsistencies in the results of previous studies regarding the relationship between role stress on turnover intentions. Research by Fogarty et al., (2000), states a positive relationship between role stress on the desire to move. This is supported by the research of Johartono \& Widuri (2013), which shows that there is a significant positive relationship between job stress and turnover intention, where research is carried out by the tax consultant office in Surabaya. The research of Himawantara \& Astika (2018), showed that role conflict and role ambiguity had a positive effect on turnover intentions, but role overload had no significant effect on turnover intentions, this study was conducted at 15 Tax Consultant Offices in Denpasar City. Hopkins et al., (2010), state that the burden and responsibility received by employees will result in work stress because the goals that have been set may not be achieved due to the problems and pressures they receive, and ultimately will result in employees wanting to move to other companies. Shahzad et al., (2011), stated the same opinion, namely suggesting that stress can have a positive effect on employee turnover intention.

While the results of research conducted by Glissmeyer et al., (2007), showed different results namely role stress (role conflict and role obscurity) did not affect the intensity of exit. When an employee has a high role conflict, it is not indicated by the behavior to leave the organization with law enforcement officers. The above results are supported by Putri (2016), which shows there is no influence between work stress on turnover intention. Great job responsibilities are given by the hospital. Surakarta's Islam towards employees turns out to make employees more satisfied in their work, because given more jobs, the salary they provide will increase, with high salaries the employees will feel more passionate about their work so that the stress level of the employees is not too high. Senatra's (1980), study also shows that there is no relationship between role stress (role conflict and role ambiguity) with turnover intentions. (Farrastama

Dwiputra, I. M. A., \& Astika, I. B. P. (2019). Ability of organizational commitment and emotional intelligence moderating effect of role stress on turnover intention. International Research Journal of Management, IT and Social Sciences, 6(4), 44-53. https://doi.org/10.21744/irjmis.v6n4.641 
et al., 2019) also shows that work stress does not affect the intensity of outreach to the production staff of PT Longvin Indonesia Sukabumi. Job stress is not the main cause of the intensity of exit from the employees of the production section of PT. Longvin Indonesia Sukabumi, the biggest contribution to the turnover tendency is because the Long shift working time system has an effect on employee health.

The inconsistency of the results of research related to the influence of role stress on turnover intentions encouraged the writer to add moderating variables. The difference in the results of these studies can be solved through a contingency approach (Govindarajan, 1986). According to Murray (1990), in order to reconcile conflicting results a contingency approach is needed to identify other variables that act as moderators or mediators in the research model. Researchers suspect organizational commitment and emotional intelligence can moderate the influence of role stress on turnover intentions.

Wiener (1982), defines organizational commitment as an encouragement from the individual to do something in order to support the success of the organization in accordance with the goals and prioritize the interests of the organization rather than its own interests. In this view, individuals who have a high commitment will prioritize the interests of their organization rather than their personal or group interests. Organizational commitment will be important if the individuals involved in an organization have the will to do everything they can for the interests of the organization (Ikhsan \& Ishak (2005); Krisnanda et al., (2019); Kusumanegara et al., (2018).

Mowday et al., (1982), defines organizational commitment as meaning more than passive loyalty but involves active relationships and employee desires to make meaningful contributions to the organization. Organizational commitment proposed by Mowday et al., (1982), has characteristics, namely: (1) strong belief and acceptance of organizational goals and values; (2) readiness to work hard; and (3) a strong desire to survive in the organization. Research by Kharismawati \& Dewi (2016), shows that organizational commitment has a negative effect on turnover intentions. The results of the study are supported by the research of Andini (2016); Sidharta \& Margaretha (2011) and Witasari (2009), who also find organizational commitment negatively influencing turnover intentions.

Emotional intelligence is the ability to recognize and regulate the emotions of oneself and others, and use those emotions to guide thoughts and actions (Giardini \& Frese, 2006; Mayer et al., 2008: Gondal \& Husain, 2012). The ability of a person to motivate themselves, survive facing frustration, regulate moods, and keep the stress burden from paralyzing the ability to think, is a characteristic of someone who has good emotional intelligence (Goleman, 2004). When emotional intelligence can be managed well by someone, then this can motivate someone to deal with demands and pressure from outside.

According to Uno (2010), the more complex the work, the more important emotional intelligence. Emotions that are out of control can make smart people stupid. Without emotional intelligence, a person will not be able to use their cognitive abilities according to their maximum potential. Well-developed emotional intelligence most likely will succeed in their lives because they are able to master the thinking habits that drive productivity.

The difference between this research and previous research is using internal factors from individuals as moderating variables, namely emotional intelligence and organizational commitment to influence role stress on turnover intentions. Previous research more often used variables from individual external factors as moderating variables of the influence of stress on turnover intentions, such as the research of Himawantara \& Putra (2018), which examined the effect of role stress on tax consultant turnover intentions with compensation as moderating variables, and research by Putra (2015), examine the effect of work stress and salary satisfaction on turnover intentions with gender as a moderating variable. In addition, this study examines the phenomenon of turnover intentions in the consultant office in Bali, where research is still rare about the same phenomenon, especially in the tax consultant office located in Bali.

\section{The Effects of Role Stress on Turnover Intentions}

Role conflict is defined by Wolfe \& Snoek (1962), as simultaneous events of two or more pressures such as obedience to one thing will make it difficult or impossible to obey the other. Kahn et al., (1964), stated that role ambiguity in the absence of adequate information that someone needs to carry out his role in a satisfying manner. Rahmawati (2011), states that someone who experiences role ambiguity tends to experience a decrease in physical and psychological health. Agustina (2009), states that the absence of planning regarding good labor needs can cause auditors to experience role overload, especially during the busy season where the CTF will be flooded with work and experience time pressures. Kawiana et al., 2018, describes that a person's excessive workload can cause role pressure, especially if the workload is not in accordance with the time and capabilities it has. The research of Arshadi \& Damiri (2013), produces empirical evidence of the positive influence of role stress on turnover intentions. The results of this study are supported by the research of Pradana \& Salehudin (2015); Basri (2012); Ksama \& Wibawa (2016); Hopkins 
(2010); Sudarmawan \& Putra (2017); Pant et al., (2016); Widiani et al., (2019), which prove the existence of a positive relationship with role stress on turnover intentions. The high level of stress felt by tax consultants will have an impact on decreasing job satisfaction and work discomfort which will lead to turnover intentions. Based on the description, the formulation of the hypothesis in this study are:

H1: The higher the role stress, the more turnover intentions in the Tax Consultant Office in the Province of Bali.

\section{Organizational Commitment Moderates the Effects of Role Stress on Turnover Intentions}

The consequences of stress experienced by the tax concession will cause turnover intentions, which will cause losses to the tax consultant office. The research of Arshadi \& Damiri (2013) produced empirical evidence of the positive relationship of role stress on turnover intentions. The results of this study are supported by the research of Pradana \& Salehudin (2015); Basri (2012); Ksama \& Wibawa (2016); Hopkins (2010); and Sudarmawan \& Putra (2017), which prove the existence of a positive relationship with role stress on turnover intentions. This can be avoided by organizational commitment owned by tax consultants. Organizational commitment is one of the factors that are considered capable of influencing the influence of role stress on turnover intentions. Kartika (2011), suggested a negative relationship between organizational commitment and intention to leave, the higher organizational commitment, the lower the desire to leave the organization. This study was supported by research by Rismawan $e$ al., (2014) and Weldy (2015), show that affective commitment as part of organizational commitment is one of the main factors that can reduce turnover intentions. Based on the description, the formulation of the hypothesis in this study are:

H2: The effect of role stress on turnover intentions will decrease, with increasing organizational commitment in the Tax Consultant Office in the Province of Bali.

\section{Emotional Intelligence Moderates the Effects of Role Stress on Turnover Intentions}

Tax consultants are one profession that is susceptible to stress, this can lead to pressures that lead to emotional fatigue experienced by tax consultants. The research of Arshadi \& Damiri (2013), produced empirical evidence of the positive relationship of role stress on turnover intentions. The results of this study are supported by the research of Pradana \& Salehudin (2015); Basri (2012); Ksama (2016), Hopkins (2010); and Sudarmawan \& Putra (2017), which prove the existence of a positive relationship with role stress on turnover intentions. Stress can have a positive or negative impact. Wikaningtyas (2007), states that there are two types of stress, eustress, which have a positive impact on human life and distress that has a negative impact. Stress at a certain level can actually motivate someone to improve performance and complete their work. Some people are said to be able to positively utilize stress to capture opportunities and perform with or near their maximum level of ability. Emotional intelligence is one of the things that can direct the stress experienced by a tax consultant in a positive direction. Ismail (2009); Wiguna et al., (2019); Yunita et al., (2019), explained that good emotional intelligence will improve individual competence and the ability of individuals to deal with stresses and improve their positive attitudes and behaviors. If emotional intelligence can be managed properly, then this can motivate someone to deal with problems in their duties and improve the ability to complete tasks and improve the memory they have, so that in the future the performance they will produce will be better. Based on the description, the formulation of the hypothesis in this study are:

H3: The effect of role stress on turnover intentions will decrease, with increasing emotional intelligence in the Tax Consultant Office in Bali Province.

\section{Materials and Methods}

This research was conducted at the Tax Consultant Office (KKP) in Bali Province. The number of KKP studied in this study was $35 \mathrm{KKP}$. The population used in this study is all tax consultants at the Tax Consultant Office throughout the Province of Bali. Samples were taken by purposive sampling method, which is random sampling based on certain criteria. The criteria used as the basis for the selection of sample members in this study are as follows: (1) still an active status that is not limited to position, both as a partner, manager / assistant manager, supervisor, and junior consultant; (2) at least have a minimum work period of 1 year because according to Sweeney \& Summer (2002), that at the end of the busy season the accounting profession experiences a significant increase in emotional exhaustion, so that if you

Dwiputra, I. M. A., \& Astika, I. B. P. (2019). Ability of organizational commitment and emotional intelligence moderating effect of role stress on turnover intention. International Research Journal of Management, IT and Social Sciences, 6(4), 44-53. https://doi.org/10.21744/irjmis.v6n4.641 
have worked at least 1 year you have experienced annual SPT reporting where is a busy season for tax consultants. The data in this study were analyzed using moderating regression (Moderated Regression Analysis / MRA).

\section{Results and Discussions}

The statistical testing model used in this study is regression analysis. Regression analysis is used to see the dependence of the dependent variable with one or more independent variables. The aim is to estimate the average value of the dependent variable based on the value of the known independent variable. This study uses the Moderated Regression Analysis (MRA) which contains interactions between the multiplications of two or more dependent variables. The results of testing the effect of role stress on turnover intentions moderated by variable organizational commitment and emotional intelligence can be seen in Table 1.

Table 1

Moderated Regression Analysis (MRA)

\begin{tabular}{llll}
\hline Variable & $\mathrm{B}$ & $\mathrm{T}$ & Sig. \\
\hline Constant & 14,841 & 28,843 & 0,000 \\
Role Stress & 0,630 & 2,447 & 0,015 \\
Organizational Commitment & $-0,599$ & $-2,298$ & 0,023 \\
Emotional Intelligence & $-0,060$ & $-0,235$ & 0,814 \\
Role Stress* Organizational Commitment & $-0,625$ & $-1,989$ & 0,048 \\
Role Stress* Emotional Intelligence & $-0,608$ & $-1,995$ & 0,048 \\
\hline R Square & 0,121 & & \\
Sig. F & 0,000 & & \\
\hline
\end{tabular}

Primary Data, 2019

F Test

Based on Table 1, it can be seen that the level of significance produced is 0,000 less than $\alpha=0.05$. Thus, this research model is feasible to be used to prove the hypothesis that was formed.

\section{Determination Coefficient Test (R2)}

Based on Table 1, it can be seen that the magnitude of R-Square is 0.121 , which means that 12.1 percent of the dependent variable turnover intentions can be explained by role stress, organizational commitment, and emotional intelligence. While the remaining 87.9 percent is influenced by other variables not included in this research model.

\section{T-Test}

Based on Table 1 the value of $\mathrm{t}$ count for role stress interaction variables and organizational commitment is -1.989 with a significance level of 0.048 where the value is less than 0.05 . This proves that the organizational commitment variable is able to weaken the positive influence of role stress on turnover intentions. While the value of $\mathrm{t}$ count for role stress interaction variables and emotional intelligence is -1.995 with a significance level of 0.048 where the value is less than 0.05 . This proves that the emotional intelligence variable is able to weaken the positive influence of role stress on turnover intentions.

\section{The Effects of Role Stress on Turnover Intentions}

Based on the results of simple linear regression analysis in Table 1, the results show that role stress has a positive and significant effect on intentions of tax consultant intentions in the Bali Region. This is indicated by a significance value of 0,000 whose value is smaller than the specified level of significance $(\alpha=0.05)$ so that the first hypothesis (H1) is accepted, namely higher role stress, increasing turnover intentions at the Tax Consultant Office in the Province of Bali. The results of this study are consistent with previous studies namely Pradana \& Salehudin (2015); Basri (2012); 
Ksama (2016); Hopkins (2010); and Sudarmawan \& Putra (2017), which prove the existence of positive role stress relationships on turnover intentions. The results of this study support the work stress model theory in which role conflict, ambiguous role and the weight of work pressure (role overload) can lead to stress on the tax consultant in doing his work which in turn can lead to turnover intentions.

\section{Organizational Commitment Moderates the Effects of Role Stress on Turnover Intentions}

The results of this study show that organizational commitment is able to moderate the influence of role stress on turnover intentions with B2 values of -0.625 with Sig. $=0.048$ which is smaller than $\alpha=0.05$, which means that the organizational commitment variable is able to weaken the positive influence of role stress on turnover intentions and can be interpreted when the organizational commitment of a high tax consultant will be able to reduce the tendency of a tax consultant to do the turnover intentions when role stress is high and vice versa when the organizational commitment of a tax consultant is low, it will be able to increase the positive influence of role stress on turnover intentions. So that the second hypothesis (H2) is accepted, namely the influence of role stress on turnover intentions will decrease, with increasing organizational commitment in the Tax Consultant Office in the Province of Bali. The results of this study are in line with the research conducted by Kartika (2011); Rismawan et al., (2014) and Weldy (2015), who suggested that the higher the organizational commitment, the lower the desire to leave the organization. The results of this study support affective event theory which states that events in the workplace cause emotional reactions for employees, which then affect their attitudes, behavior, performance, and job satisfaction. These emotions can affect performance and satisfaction, one of which is organizational commitment. This organizational commitment is classified as attitude commitment because it relates to the extent to which individuals feel their personal values and goals are in accordance with the values and goals of the organization. The greater the congruence between the values and goals of individuals and the values and objectives of the organization, the higher the commitment of employees to the organization.

\section{Emotional Intelligence Moderates the Effects of Role Stress on Turnover Intentions}

The results of this study show that emotional intelligence is able to moderate the effect of role stress on turnover intentions with a beta coefficient of -0.608 with the Sig. $=0.048$ which is smaller than $\alpha=0.05$, which means that the emotional intelligence variable is able to weaken the positive influence of role stress on turnover intentions and can be interpreted when emotional intelligence possessed by a high tax consultant will be able to reduce the tendency of a tax consultant to do the turnover intentions when role stress he feels are high and vice versa when emotional intelligence possessed by a tax consultant is low, it will be able to increase the positive influence of role stress on turnover intentions decreasing, with increasing emotional intelligence in the Tax Consultant Office in the Province of Bali. The results of this study are in line with the research conducted by Trivellas et al., (2013); Madamang (2015) and Lee \& Liu (2007), which suggest that the higher emotional intelligence, the lower the desire to leave the organization.

Emotional intelligence is the ability to recognize and regulate the emotions of oneself and others, and use those emotions to guide thoughts and actions (Giardini \& Frese, 2006; Mayer et al., 2008: Gondal \& Husain, 2012). The ability of tax consultants to motivate themselves, survive facing frustration, regulate moods, and keep the stress burden from paralyzing thinking skills, is a feature of tax consultants who have good emotional intelligence. When emotional intelligence can be managed properly by a tax consultant, then this can motivate to deal with demands and pressure from the outside so that it can reduce the stress that can have an impact on turnover intention.

The results of this study support affective event theory which states that events in the workplace cause emotional reactions for employees, which then affect their attitudes, behavior, performance, and job satisfaction. These work events can lead to positive reactions or negative reactions.

\section{Conclusion}

This study found that role stress has a significant positive effect on turnover intentions, so KKP here must improve the chain of responsibilities of each employee so that all employees know what their responsibilities are. In addition, it must always be at the level of togetherness between employees so that there is no conflict that will cause stress. The results also show that organizational commitment can reduce turnover intentions from tax consultants when experiencing role stress. So here the CTF must always have a vision and mission that is in line with its employees so

Dwiputra, I. M. A., \& Astika, I. B. P. (2019). Ability of organizational commitment and emotional intelligence moderating effect of role stress on turnover intention. International Research Journal of Management, IT and Social 
that employee loyalty to the KKP is maintained so that the desire to move from the CTF can be lowered. The results also show that emotional intelligence weakens the turnover intentions of tax consultants when experiencing role stress. KKP also has to control the emotional level of its tax consultant so that work stress does not occur, one of the activities that can be done by the CTF is to do yoga or travel to nature that can eliminate boredom and also be calmer later facing work. When working in a calm situation will produce better and more accurate work.

\section{Research Limitation}

This study has limitations on conclusions based on turnover intentions from registered tax consultants who have a license to practice in the Bali Region alone so that they cannot be generalized to all tax consultants in Indonesia. Subsequent research can use this research as one of the references on turnover intentions of registered tax consultants who have practice licenses in other regions. The researcher used a survey method with a questionnaire technique to collect data so that it had limitations in disclosing deep problems related to tax consultant intentions turnover. Subsequent research can be done with direct interview techniques to get more in-depth disclosures about the behavior of tax consultants.

Conflict of interest statement and funding sources

The authors declared that they have no competing interest.

Statement of authorship

The authors have a responsibility for the conception and design of the study. The authors have approved the final article.

\section{Acknowledgments}

The authors would like to thank the Editor of IRJMIS for their valuable time, support, and advice in completing the current study. 


\section{References}

Agustina, L. (2011). Pengaruh Konflik Peran, Ketidakjelasan Peran, dan Kelebihan Peran terhadap Kepuasan Kerja dan Kinerja Auditor (Penelitian pada Kantor Akuntan Publik yang Bermitra Dengan Kantor Akuntan Publik Big Four di Wilayah DKI Jakarta). Jurnal Akuntansi Maranatha, 1(1), 40-69.

Andini, R. (2010). Analisis pengaruh kepuasan gaji, kepuasan kerja, komitmen organisasional terhadap turnover intention. Dinamika Sains, 8(16).

Arshadi, N., \& Damiri, H. (2013). The relationship of job stress with turnover intention and job performance: Moderating role of OBSE. Procedia-Social and Behavioral Sciences, 84, 706-710. https://doi.org/10.1016/j.sbspro.2013.06.631

Basri, Y. M. (2012). Hubungan Antara Keadilan Prosedural, Job Stress, Komitmen Organisasi dan Keinginan Berpindah (Study pada Tenaga Akuntansi di Provinsi Riau dan Kabupaten Bengkalis). Jurnal Akuntansi (Media Riset Akuntansi \& Keuangan), 1(1), 23-37.

Breakwell, G. M. (1990). Are you stressed out. The American journal of nursing, 90(8), 31-33. https://doi.org/110.2307/3463949

Ermawati, M. D., Sinarwati, N. K., \& Edy Sujana, S. E. (2014). Pengaruh Role Stress Terhadap Kinerja Auditor dengan Emotional Quotient Sebagai Variabel Moderating (Studi Empiris pada Kantor Akuntan Publik di Bali). JIMAT (Jurnal Ilmiah Mahasiswa Akuntansi) Undiksha, 2(1).

Farrastama, D. N., Asmony, T., \& Hermanto, H. (2019). Effect of emotional intelligence on counterproductive work behavior with job stress as an intervening variable. International Journal of Social Sciences and Humanities, 3(1), 14-25. https://doi.org/10.29332/ijssh.v3n1.248

Fogarty, T. J., Singh, J., Rhoads, G. K., \& Moore, R. K. (2000). Antecedents and consequences of burnout in accounting: Beyond the role stress model. Behavioral Research in Accounting, 12, 31-68.

Gaertner, J. F., \& Ruhe, J. A. (1981). Job-related stress in public accounting: CPAs who are under the most stress and suggestions on how to cope. Journal of Accountancy (pre-1986), 151(000006), 68.

Giardini, A., \& Frese, M. (2006). Reducing the negative effects of emotion work in service occupations: Emotional competence as a psychological resource. Journal of Occupational Health Psychology, 11(1), 63.

Glissmeyer, M., Bishop, J. W., \& Fass, R. D. (2007). Role Conflict, Role Ambiguity and Intention to Quit the Organization: The Case of Law Enforcement Officers. In Decision Sciences Institute Annual Conference, 38th Southwest.

Goleman, D., Boyatzis, R., \& Mckee, A. (2004). Kepemimpinan berdasarkan kecerdasan emosi. Terjemahan Susi Purwoko. Jakarta: Gramedia Pustaka Utama.

Gondal, U. H., \& Husain, T. (2013). A comparative study of intelligence quotient and emotional intelligence: effect on employees' performance. Asian journal of Business management, 5(1), 153-162.

Govindarajan, V. (1986). Impact of participation in the budgetary process on managerial attitudes and performance: Universalistic and contingency perspectives. Decision Sciences, 17(4), 496-516. https://doi.org/10.1111/j.15405915.1986.tb00240.x

Hamzah, U. (2010). Orientasi dalam Psikologi Pembelajaran. Bandung: Cetakan ke, 4.

Hopkins, K. M., Cohen-Callow, A., Kim, H. J., \& Hwang, J. (2010). Beyond intent to leave: Using multiple outcome measures for assessing turnover in child welfare. Children and Youth Services Review, 32(10), 1380-1387. https://doi.org/10.1016/j.childyouth.2010.06.006

Ikhsan, A., \& Ishak, M. (2005). Akuntansi keperilakuan. Jakarta: salemba empat.

Ismail, A., Suh-Suh, Y., Ajis, M. N. E., \& Dollah, N. F. (2009). Relationship between Occupational Stress, Emotional Intelligence and Job Performance: An Empirical Study in Malaysia. Theoretical \& Applied Economics, 16(10).

Johartono, J., \& Widuri, R. (2013). Analisa Pengarush Stres Kerja, Kepuasan Kerja, Budaya Organisasi, dan Komitmen Organisasi terhadap Turnover Intention Karyawan Kantor Konsultan Pajak di Surabaya. Tax \& Accounting Review, 3(2), 162.

Jones III, A., Norman, C. S., \& Wier, B. (2010). Healthy lifestyle as a coping mechanism for role stress in public accounting. Behavioral Research in Accounting, 22(1), 21-41.

Kahn, R. L., Wolfe, D. M., Quinn, R. P., Snoek, J. D., \& Rosenthal, R. A. (1964). Organizational stress: Studies in role conflict and ambiguity.

Kartika, E. W. (2011). Analisis pengaruh leader-member exchange, perceived organizational support, dan komitmen organisasional terhadap organizational citizenship behavior pada karyawan hotel berbintang lima di Surabaya. Surabaya: Universitas Airlangga.

Dwiputra, I. M. A., \& Astika, I. B. P. (2019). Ability of organizational commitment and emotional intelligence moderating effect of role stress on turnover intention. International Research Journal of Management, IT and Social Sciences, 6(4), 44-53. https://doi.org/10.21744/irjmis.v6n4.641 
Kawiana, I. G. P., Dewi, L. K. C., Martini, L. K. B., \& Suardana, I. B. R. (2018). The influence of organizational culture, employee satisfaction, personality, and organizational commitment towards employee performance. International Research Journal of Management, IT and Social Sciences, 5(3), 35-45.

Kharismawati, D. A. P., \& Dewi, I. G. A. M. (2016). Pengaruh Komitmen Organisasional, Dukungan Sosial, dan Iklim Etika terhadap Turnover Intention. None, 5(2).

Krisnanda, P. H., \& Surya, I. B. K. (2019). Effect of emotional and spiritual intelligence on transformational leadership and impact on employee performance. International Research Journal of Management, IT and Social Sciences, 6(3), 70-82. https://doi.org/10.21744/irjmis.v6n3.634

Ksama, I. B. P. T., \& Wibawa, I. M. A. Pengaruh Leader-member Exchange, Role Stress Dan Perceived Organizational Support Terhadap Turnover Intention. None, 5(10).

Kusumanegara, I. S., Asmony, T., \& Numayanti, S. (2018). Work-family conflict on turnover intention regarding work stress as intervening variable. International Journal of Social Sciences and Humanities, 2(2), 141-154. https://doi.org/10.29332/ijssh.v2n2.153

Lee, H. W., \& Liu, C. H. (2007). An examination of factors affecting repatriates' turnover intentions. International Journal of manpower, 28(2), 122-134. https://doi.org/10.1108/01437720710747956

Madamang, I. (2015). Peran Kecerdasan Emosional Dan Stres Kerja Terhadap Turnover Intentions Di Rumah Sakit Swasta Kendari (Doctoral dissertation, Fakultas Ekonomi UNISSULA).

Mayer, J. D., Caruso, D. R., \& Salovey, P. (1999). Emotional intelligence meets traditional standards for an intelligence. Intelligence, 27(4), 267-298. https://doi.org/10.1016/S0160-2896(99)00016-1

Mowday, R. T., Porter, L. W., \& Steers, R. M. (2013). Employee-organization linkages: The psychology of commitment, absenteeism, and turnover. Academic press.

Murray, D. (1990). The performance effects of participative budgeting: An integration of intervening and moderating variables. Behavioral Research in Accounting, 2(2), 104-123.

Pant, I., \& Yadav, R. K. (2016). Impact of emotional intelligence on the job performance of employee. International Research Journal of Management, IT and Social Sciences, 3(1), 7-14.

Pradana, A., \& Salehudin, I. (2015). Work overload and turnover intention of junior auditors in greater Jakarta, Indonesia. The South East Asian Journal of Management, 9(2), 108-124.

Putra, R. P. (2015). Intention dengan Gender sebagai Variabel Moderating (Studi pada Kantor Akuntan Publik di Yogyakarta dan Surakarta). Nominal, Barometer Riset Akuntansi dan Manajemen, 4(1).

Putri, R. H., \& Djastuti, I. (2013). Analisis pengaruh stres kerja dan konflik pekerjaan-keluarga (work family conflict) terhadap kinerja karyawan melalui kepuasan kerja sebagai variabel intervening (Studi pada PT. ARA Shoes Indonesia)(Doctoral dissertation, Fakultas Ekonomika dan Bisnis).

Rethinam, G. S., \& Ismail, M. (2008). Constructs Of Quality Of Work Life: A Perspective Of Information Technology Professionals. European journal of social sciences, 1.

Rismawan, P. A. E., Supartha, W. G., \& Yasa, N. N. K. (2014). Peran mediasi komitmen organisasional pada pengaruh stress kerja dan kepuasan kerja Terhadap intensi keluar karyawan. E-Jurnal Ekonomi dan Bisnis Universitas Udayana.

Senatra, P. T. (1980). Role conflict, role ambiguity, and organizational climate in a public accounting firm. Accounting Review, 594-603.

Shahzad, K., Rehman, U., Shad, I., Gul, A., \& Amnulah Khan, M. (2011). Work-life policies and job stress as determinants of turnover intentions of customer service representatives in Pakistan. European journal of social sciences, 19(3), 403-411.

Sidharta, N., \& Margaretha, M. (2011). Dampak komitmen organisasi dan kepuasan kerja terhadap turnover intention: studi empiris pada karyawan bagian operator di salah satu perusahaan garment di Cimahi. Jurnal Manajemen, 10(2), 129-142.

Sudarmawan, P. S. K., \& Putra, I. N. W. A. (2017). Pengaruh Role Stress Pada Turnover Intentions Auditor dengan Komitmen Afektif Sebagai Variabel Pemoderasi. E-Jurnal Akuntansi, 2000-2027.

Sudarmawan, P. S. K., \& Putra, I. N. W. A. (2017). Pengaruh Role Stress Pada Turnover Intentions Auditor dengan Komitmen Afektif Sebagai Variabel Pemoderasi. E-Jurnal Akuntansi, 2000-2027.

Sweeney, J. T., \& Summers, S. L. (2002). The effect of the busy season workload on public accountants' job burnout. Behavioral Research in Accounting, 14(1), 223-245. https://doi.org/10.2308/bria.2002.14.1.223

Trivellas, P., Gerogiannis, V., \& Svarna, S. (2013). Exploring workplace implications of Emotional Intelligence (WLEIS) in hospitals: Job satisfaction and turnover Intentions. Procedia-Social and Behavioral Sciences, 73, $701-$ 709. https://doi.org/10.1016/j.sbspro.2013.02.108 
Wayne, R. (1990). Mondy. Robert M,. Noe. Human Resource Management”, Edition USA: Allyn and Bacon.

Weldy, G. E. (2016). Pengaruh Tekanan Peran Dalam Pekerjaan Dan Komitmen Organisasi Terhadap Keinginan Untuk Berpindah Tempat Kerja (Studi Empiris Pada Auditor Kap Di Kota Malang). Jurnal Ilmiah Mahasiswa $F E B, 3(2)$.

Widiani, N. P., Putri, A. M. A. D., Sari, M. M. R., \& Wirajaya, I. G. A. (2019). The effect of love of money and emotional intelligence on employee performance with organizational citizenship behavior as mediating variable. International Research Journal of Engineering, IT \& Scientific Research, 5(1), 39-49. https://doi.org/10.21744/irjeis.v5n1.596

Wiener, Y. (1982). Commitment in organizations: A normative view. Academy of management review, 7(3), $418-428$. https://doi.org/10.5465/amr.1982.4285349

Wiguna, I. P. I., \& Yadnyana, K. (2019). The role of working experience moderating the effect of emotional intelligence, intellectual intelligence, and spiritual intelligence on the ethical decision of tax consultants in Bali area. International Research Journal of Management, IT and Social Sciences, 6(3), 18-28. https://doi.org/10.21744/irjmis.v6n3.624

Wikaningtyas, T. S. (2007). Hubungan Antara Perilaku Tipe A dan Tipe B dengan Stres Kerja. E-Jurnal Fakultas Psikologi, Universitas Indonesia.

Wirakusuma, M. G., Rasmini, N. K., \& Wiryathi, N. M. (2014). Pengaruh Role Stressors pada Burnout Auditor dengan Kecerdasan Emosional sebagai Variabel Pemoderasi (Studi Empiris pada Kantor Akuntan Publik Se-provinsi Bali). E-Jurnal Ekonomi dan Bisnis Universitas Udayana.

Witasari, L. (2009). Analisis pengaruh kepuasan kerja dan komitmen organisasional terhadap turnover intentions (studi empiris pada Novotel Semarang) (Doctoral dissertation, Universitas Diponegoro).

Wolfe, D. M., \& Snoek, J. D. (1962). A Study of Tensions and Adjustment Under Role Conflict1. Journal of Social Issues, 18(3), 102-121. https://doi.org/10.1111/j.1540-4560.1962.tb00419.x

Yousef, D. A. (2002). Job satisfaction as a mediator of the relationship between role stressors and organizational commitment: A study from an Arabic cultural perspective. Journal of managerial psychology, 17(4), 250-266. https://doi.org/10.1108/02683940210428074

Yunita, P. I., \& Saputra, I. G. N. W. H. (2019). Millennial generation in accepting mutations: Impact on work stress and employee performance. International Journal of Social Sciences and Humanities, 3(1), 102-114. https://doi.org/10.29332/ijssh.v3n1.268

Dwiputra, I. M. A., \& Astika, I. B. P. (2019). Ability of organizational commitment and emotional intelligence moderating effect of role stress on turnover intention. International Research Journal of Management, IT and Social Sciences, 6(4), 44-53. https://doi.org/10.21744/irjmis.v6n4.641 